\title{
Evaluation of Indonesian Anti-obesity Traditional Medicinal Plants: A Systematic Review and Meta- analysis on Pancreatic Lipase Inhibition Activity
}

Hasim Hasim ( $\sim$ hasim@apps.ipb.ac.id )

IPB University: Institut Pertanian Bogor

Didah Nur Faridah

Bogor Agricultural University: Institut Pertanian Bogor

Frendy Ahmad Afandi

Ministry of Economy and Development

Eka Nurul Qomaliyah

Bogor Agricultural University: Institut Pertanian Bogor

\section{Research}

Keywords: antiobesity, ethnopharmacology, Indonesian medicinal plants, lipase pancreas inhibition, meta-analysis

Posted Date: September 15th, 2021

DOI: https://doi.org/10.21203/rs.3.rs-885615/v1

License: (c) (i) This work is licensed under a Creative Commons Attribution 4.0 International License. Read Full License 


\section{Evaluation of Indonesian Anti-obesity Traditional Medicinal Plants: A}

\section{Systematic Review and Meta-analysis on Pancreatic Lipase Inhibition}

\section{Activity}

\section{Hasim $^{1 *+}$, Didah Nur Faridah ${ }^{2,3}$, Frendy Ahmad Afandi ${ }^{4+}$, Eka Nurul Qomaliyah ${ }^{1+}$}

1 Department of Biochemistry, IPB University, Bogor 16880, Indonesia

Department of Food Science and Technology, IPB University, Bogor 16880, Indonesia

3 Southeast Asian Food and Agricultural Science and Technology (SEAFAST) Center, IPB University, Bogor 16880, Indonesia

Deputy Ministry for Food and Agribusiness, Coordinating Ministry for Economic Affairs

* Correspondence: hasim@apps.ipb.ac.id

+ These authors contributed equally to this work

\section{Abstract}

Background: Researches and publication discussing performance of medicinal plants as anti-obesity have proliferated in recent years. In the view of ethnopharmacology, empiric evidence of Indonesian medicinal plants in management of obesity is widely accepted. In attempt to find anti-obesity agent, it is evidenced that the disorder can be resolved through inhibition of pancreatic lipase since the mechanism allowed to retard absorption of fat into cells. This current work aimed to screen Indonesian medicinal plants by using ethnopharmacology and meta-analysis approaches, emphasizing their ability to deal with obesity via pancreatic lipase inhibition.

Methods: The study followed two stages, i.e. systematic review and meta-analysis. Data from 6 scientific (Scopus, Science Direct, Proquest, Ebsco, Cengage Library and Emerald) were collected, screened according to inclusion and exclusion criteria. The eligibility of the trials was determined according to criteria as follows: (1) design for lipase inhibition experiments; (2) population in all researches using in vitro protocols for antiobesity in last 10 years; (3) intervention for comparison between lipase inhibition IC50 properties of selected medicinal plants and orlistat; and (4) data adequacy enabling to estimate the standardized mean difference (SMD) and the corresponding 95\% confidence interval (CI). Further, all published papers we reviewed were written in English. Furthermore, steps of meta-analysis were performed on the selected data. Extraction of data in these articles collected number of 
samples, average values and standard deviation of IC50. The values focused on IC50 of samples in inhibiting lipase activities performed by plant extracts and orlistat as control.

Result: A total 10 selected data meet the inclusion criteria. Morever these plant can be found and common as traditional medicine plant in Indonesia

Conclusion: As the results, there were top 10 anti-obesity medicinal plants as follows: i.e. kelor (Moringa oleifera) leaves, kemangi (Ocimum basilicum) leaves, asam jawa (Tamarindus indica) leaves, asam gelugur (Garcinia atroviridis) fruit, lengkuas (Alpinia galanga) rhizome, and kencur (Kaempferia galanga) rhizome, kumis kucing (Orthosipon aristatus) leaves, jambu biji leaves (Psidium guajava leavaes), serai wangi (Cymbopogon nardus) and kayu secang (Caesalpinia sappan).

Keywords: antiobesity; ethnopharmacology; Indonesian medicinal plants; lipase pancreas inhibition; meta-analysis

\section{Introduction}

Obesity is medically characterized as excess adiposity in tissues as a result of disparity between energy intake and energy expenditure [1]. Currently, the prevalence is rising at alarming rate reaching approximately three times within 1975 - 2016, and therefore becomes health issues worldwide [2]. In 2016, WHO reported that more than 1.9 billion adults were overweight, while 650 million of them were obese. [2]. Furthermore, obesity prevalence continues to rise, not only in adults, but also in children and teenagers [3]. With a rapid growing prevalence, obesity receives serious concern since it is associated with degenerative diseases such as diabetes, heart and liver disease, stroke, hypertension, hypercholesterolemia, kidney failure and osteoarthritis [3].

In Indonesia, obesity has become foremost nutrition concern besides stunting [4]. The case in this country markedly increased in 2007-2018. Obesity proportion of Indonesian adults with body mass index (BMI) of $\geq 27$ in 2007, 2013, and 2018 reaches 10.5, 14.8, and 21.8, respectively, while the average proportion of obesity is 21.8 . Specifically, the highest proportion is found in Province of Sulawesi Utara (30.2); in contrast, the lowest one is attributed to Province of Nusa Tenggara Timur (10.3) [4]. Regarding the current obese cases, there is a need to treat obesity using therapy and medical approaches.

Medical treatments for obesity can be performed through orlistat and sibutramine [5]. Orlistat induces weight loss by alleviating intestinal fat absorption via inhibition of pancreatic lipase [6] [7]. Sibutramine (reductil) is an anorexic drug widely accepted for anti-obesity treatment, and able to reduce palatable food intake [7]. However, both drugs are then associated with deleterious side effects such as rising blood pressure, headache, insomnia, constipation and dry mouth [7]. Alternatives to these drugs are often applied to treat obesity, such as radafaxine and 
oleoyl-estrone, which modulates peripheral episodic satiety signals, i.e. rimonabant and APD356, while other drugs such as cetilistat and AOD9604 inhibit fat absorption [8,9]. The side effects of using these anti-obesity drugs are main reason for searching safe treatments of obesity, including herbal medicines [7].

Studies on the use of herbal plants for management of anti-obesity have been carried out, as attempt to find safe and healthier drugs [10]. Indonesian indigenous herbal plants vary greatly, and among them, 76 of the plants are evidenced to exert anti-obesity properties [11]. Previous researches reported performance of anti-obesity treatments using some herbal plants such as jati belanda (Guazuma ulmifolia), kemuning (Murraya paniculata) leaves, kelembak (Rheum officinale) roots, tempuyung (Sonchus arvensis) leaves [12,13]; sirih merah (Piper crocatum) [14]; asam gelugur (Garcinia atroviridis), kunci pepet, (Kaempferia rotunda), lengkuas (Alpinia galanga), daun asam Jawa (Tamarindus indica leaves), kencur (Kaempferia galanga) [15,16]; and teh hitam (Camelia sinensis)[17]. The herbs for obesity treatment registered in Permenkes No. 6 Year 2016 about Indonesian indigenous herbs-based drugs included jati belanda and kemuning.

Attempts to find the efficacy of some potential plants for anti-obesity treatment still continue, emphasizing the roles of phytochemical bioactivities. Some of the bioactive compounds were reported capable of reducing obesity, including polyphenols, saponin, alkaloid, flavonoid, and saponin [18]. How these chemicals work is intriguing, since they display different mechanisms, i.e. satiety modulation, inhibition of adipogenesis and fat absorption, as well as retardation of pancreatic lipase [19]. With the growing researches discussing the topic, some evidences elucidated how the phytochemicals work for anti-obesity treatments, grouped into 5 basic mechanisms: (1) lowering lipid absorption, (2) decreasing energy intake, (3) rising energy expenditure, (4) suppressing differentiation and proliferation of preadipocyte and (5) declining lipogenesis while enhancing lipolisis [10]. Pancreatic lipase constitutes a pivotal enzyme responsible for fat absorption into cells, and this enzymatic activity can be hindered by tetrahydroplistatin (orlistat) [10]. In this regard, inhibiting pancreatic lipase is one the key mechanism in dealing with obesity. The inhibition of lipase can be expressed as IC50 or \% inhibition.

Studies pertaining to inhibition of pancreatic lipase for anti-obesity have increased markedly worldwide. However, meta-analysis on anti-obesity treatments via pancreatic lipase restriction induced by Indonesian plant chemicals is not available. This present work aimed to screen medicinal plants originating from Indonesia that possesses anti-obesity properties based on their ability inhibit pancreatic lipase. Main data included inhibition of lipase (IC50 value) with orlistat as control. 


\subsection{Literature Search}

This research referred to the guidelines of a meta-analysis handbook [20]. Relevant studies published in various electronic databases such as Proquest, Science Direct, Ebsco, Cengage Library, and Emerald for inhibitory lipase pancreatic were identified (up to May 2021). The four studies that we used in this research can also be found in the PubMed and Embase database.

Keywords used in the search strategy included "antiobesity", "medicinal plants", "lipase inhibition", and "antihiperlipidemia". After reading the titles and abstracts, we excluded irrelevant studies using Collandrapp. Subsequently, we examined the full text of all remaining articles to determine eligibility. The discrepancies were verified by discussion and consensus. We also reviewed the identified trials and review articles in reference lists to find any other potential proper articles.

\subsection{Eligibility Criteria}

The eligibility of the trials was determined according to criteria as follows: (1) design for lipase inhibition experiments; (2) population in all researches using in vitro protocols for antiobesity in last 10 years; (3) intervention for comparison between lipase inhibition IC50 properties of selected medicinal plants and orlistat; and (4) data adequacy enabling to estimate the standardized mean difference (SMD) and the corresponding 95\% confidence interval (CI). Further, all published papers we reviewed were written in English.

\subsection{Data Extraction}

Data from each included study were extracted and integrated into the database. The following information was 104 collected: first author, year of publication, country of origin, number of experiments, intervention, control, solvent, method, and outcomes data (IC50 lipase inhibition).

\subsection{Statistical Analysis}

Calculation in meta-analysis was carried out using Hedge's method [21]. Data processing employed open 108 source software OpenMEE. Because all the observation indexes are continuous, and the measurement time of out- 
come is inconsistent across studies, we pooled the SMD with a corresponding 95\% CI using the random-effects

model. The variable used for subgroup analysis was Indonesian name of traditional medicine.

\section{Results}

\subsection{Systematic Review Diagram}

A total of 326 articles (from 810 articles) was selected for full-text review, resulting in four articles that best fit inclusion criteria. Four hundred eighty four of them were rejected due to irrelevant content. Nine additional articles from reference lists of identified trials were included in the study because they met the inclusion criteria. Then, 331 articles were excluded because they did not meet the criteria ( 8 review articles, 31 articles not discussing Indonesian medicinal plants, and 291 articles with no available data for analysis). In total, the meta-analysis involved four articles included ten Data, as exhibited in Figure 1.

Scopus: 461

Science Direct: 108

Proquest: 166

Ebsco: 2

Cengage Library: 66

Emerald: 7

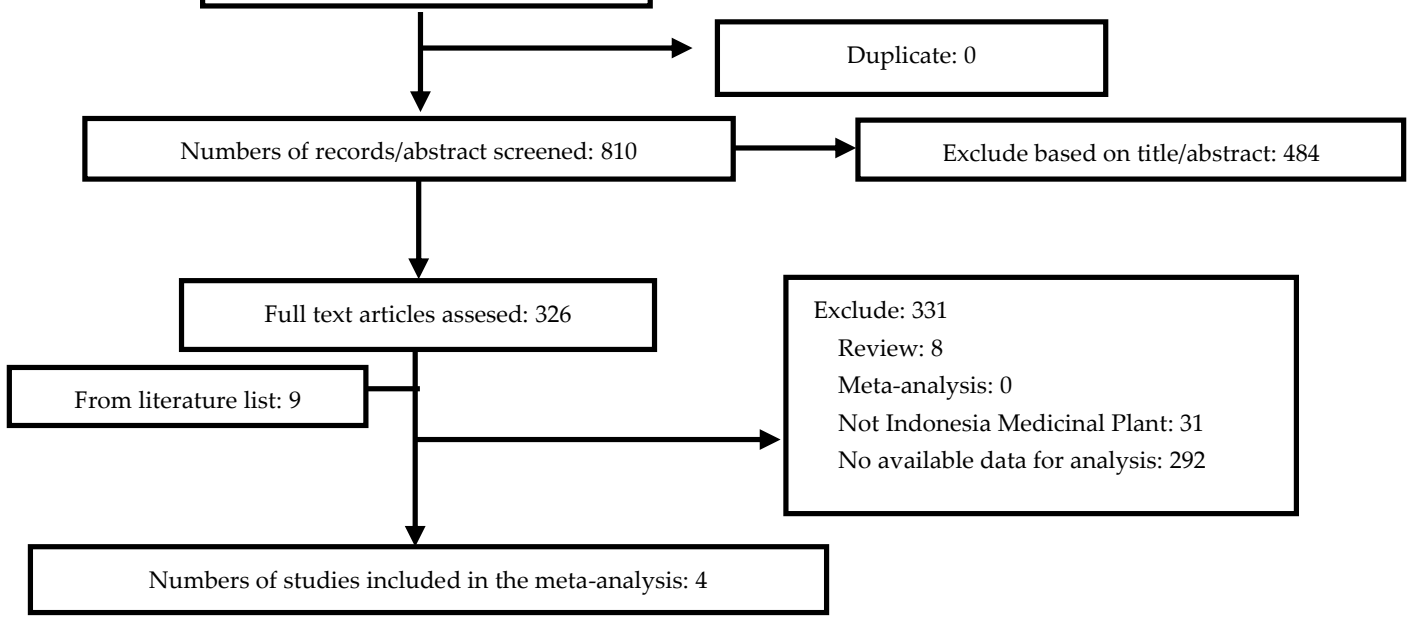

Figure 1. The PRISMA flow chart of the literature review process

\subsection{Characteristics of Articles}

Ten studies involving 30 experiments were published from 2012 to 2021 . The PICO of this research is 
medicine, i.e. orlistat was used as comparison. Outcome of this research was the best potential lipase inhibition activity by Indonesian medicinal plant. The study design used in this research was the randomized control.

3.3 Profile of pancreatic lipase inhibition by Indonesian medicinal plants.

In this work, IC50 value represents the inhibitory activity against pancreatic lipase, meaning the concentration of a drug that gives a half-maximum response. Lower value of IC50 denotes that the drug shows more powerful inhibition. As a consequence, in this work, we searched for medicinal plants with lowest value of IC50. To select the potential plants, we discarded rare or not popular plants such as johar, ginko biloba, daun seribu, delima, jeruk bali, and kapulaga sabrang. Additionally, the exclusion also referred to their IC50 close to selected medicinal plants.

Forest plot (Figure 2) exhibits average and CI 98\% of Indonesian medicinal plants displaying anti-obesity properties, i.e. $13.42[-0.05,26,89]$ with $\mathrm{I}^{2}=89.98 \%$ and $\mathrm{P}<0.001$. In this regard, we found kelor (Moringa oleifera) possessing value lower than the average, i.e. $3.61[1.70,5.52]$. Kemangi (Ocimum basillicum) also shows a relatively low IC50 in comparison with other studied plants. Therefore, referring to IC50, two Indonesian medicinal plants showing the best inhibition against pancreatic lipase were kelor and kemangi.

Kelor leaves showed a considerable inhibition of pancreatic lipase, while also significantly reducing body mass index of obese rats [22]. Using in vivo experiment, it was evidenced able to improve lipid profiles, i.e. reducing total cholesterol, triglycerides, low-density lipoprotein (LDL), very low-density lipoprotein (VLDL), increasing high-density lipoprotein (HDL), modulating fat deposition through down-regulating the expression of adipogenesis-associated proteins peroxisome proliferator-activated receptor gamma (PPAR $\gamma$ ) and fatty acid synthase (FAS), up-regulating expression of lipolytic protein (adipose triglyceride lipase (ATGL), as well as reducing leptin concentration [23]. An A previous study using 3T3-L1 cells revealed that kelor leaves could diminish expression of protein accounting for adipogenesis and lipogenesis [24]. In case of Indonesian medicinal plants, the studies discussing anti-obesity treatments worked with adiposity test under in vitro experiment (evaluation based on \% lipid accumulation and $\%$ glycerol release) involving 76 plants, as the results, red ginger (Zingiber officinale var. rubrum) showed the most effective drug on treatment of obesity. Meanwhile, kelor was also included in top 5 plants [11]. Intriguingly, kelor has been accepted as one of the top 50 future foods since it is rich in health-improving bioactivities [25]. 

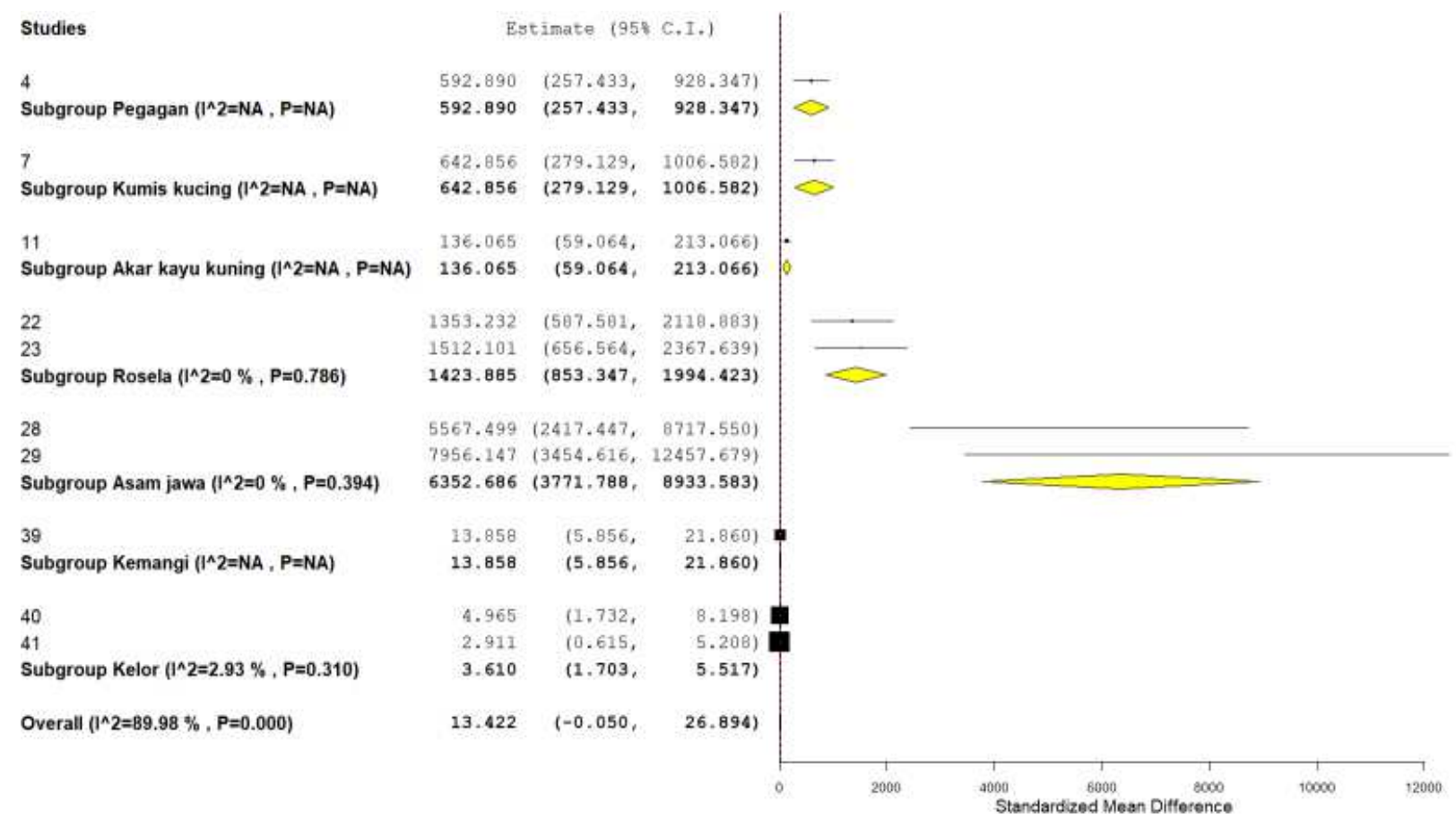

Figure 2. Forest Plot of IC50 Lipase pancreas

Note: Subgroup analysis of the lipase pancreatic inhibition capacity in Indonesian medicinal plants. Standardized mean

difference (SMD), confidence interval (CI), and point represent the estimated overall effect size (with $95 \%$ CIs) for each

\section{Discussion}

In this work, we reported phytochemicals in Indonesian medicinal plants that are able to serve as anti-lipase, 

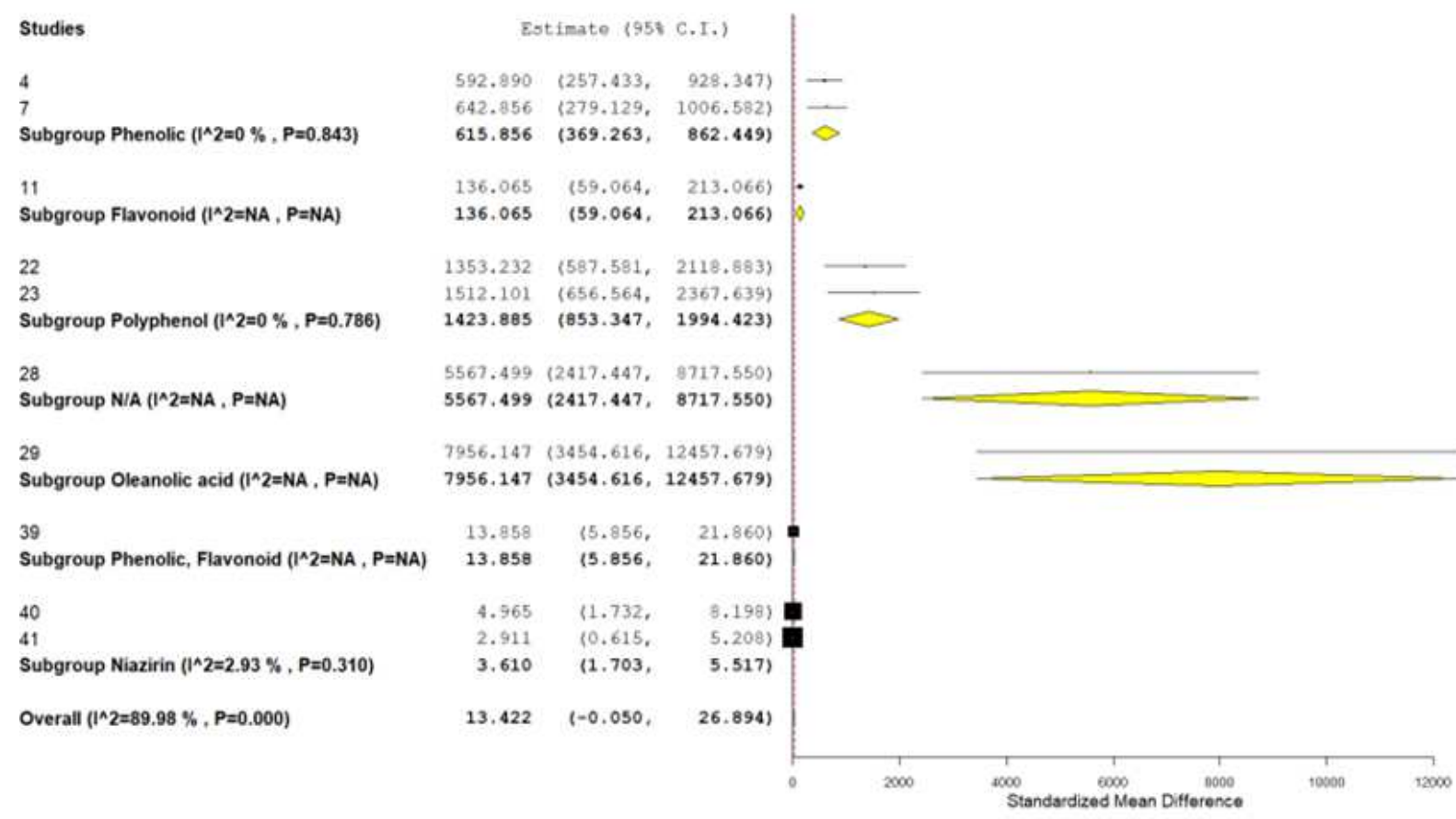

Figure 3. Forest plot of bioactive compounds from Indonesian medicinal plants.

Four main classes of phytochemicals showing anti-obesity effects are alkaloid, phytosterol, polyphenol and terpenoid [26]. Rajan et al. (2020) [27] reported 5 bioactive compounds that exert lipase inhibitory effects; and they 166 included phenolic, flavonoid, saponin, alkaloid and terpenoid. To evaluate their inhibition capacity, IC50 value of 167 lipase inhibition can be a proper indicator, resulting that flavonoid possesses low value, meanwhile the other groups 168 (saponin, terpenoid and flavonoid) show a high value of IC50. Regarding their mode of action, anti-obesity effect by 169 flavonoid relates with its ability to reduce lipid accumulation, total cholesterol and pancreatic lipase activity [28,29]. 170 Meanwhile, saponin acts as anti-obesity agent through regulation of thermogenesis, lipogenesis and lipolysis [30].

\subsection{Proper solvent for bioactive compound extraction}

Phytochemicals responsible for anti-obesity can be extracted using various solvents. As depicted in Figure 4, meta-analysis revealed that methanol showed the most proper solvent in the extraction of anti-obesity phytochemicals in

Besides methanol, phytochemicals showing pancreatic lipase inhibition can be isolated by water and ethanol. 

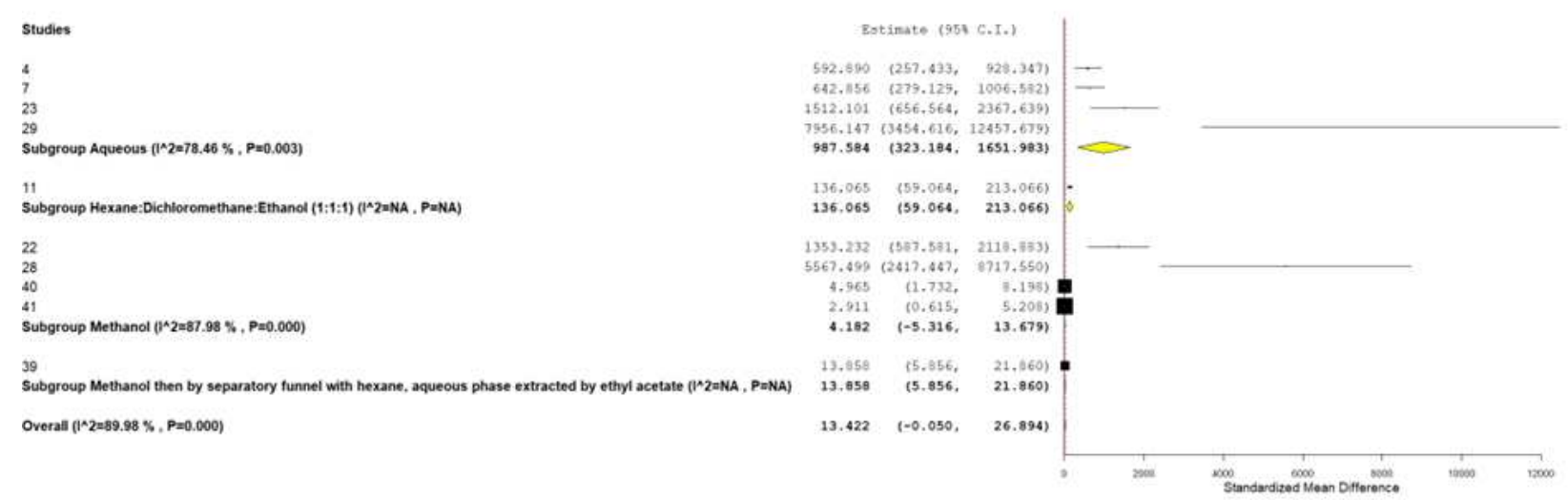

Figure 4. Forest plot of solvents applied to extract phytochemicals in Indonesian medicinal plants

\subsection{Anti-obesity performed by Indonesian medicinal plants}

We collected research data related to anti-obesity effects by Indonesian medicinal plants as well as by orlistat as control, covering IC50 value, average and standard deviation. Regarding incompletion of data, we summarized other indicators that support the analysis. Summary of data collected from various references was presented in Table 1 . The extract of medicinal plants can be a potential candidate of anti-obesity when its lipase inhibition capacity ranged $75-100 \%$. In addition, the extract with the inhibition capacity of 50-70\% and $25-50 \%$ was grouped as moderate and low, respectively, and no anti-lipase activity occurred when the capacity was $<25 \%$ [33]. After comparing the capacity for each plant, we found some plants that show high lipase pancreas inhibition capacity, including kemuning, meniran, daun kumis kucing, serai wangi, kayu secang, daun murbei, jahe, daun alpukat, jambu biji leaves, and jambu air leaves [Table 1].

Bibliometric data in Scopus database processed by VoS Viewer indicates 4 research clusters focusing on the use of medicinal plants for treatment of obesity. Each cluster color occurs differently. Studies on obesity consider experimental animal, diet, body weight, review articles and medicinal plant used. Meanwhile, studies on the effect of anti-obesity are restricted to some aspects such as inhibitory activity, high-fat diet, evaluation of anti-obesity, pancreatic lipase and medicinal plants linked to their phytochemical profiles (Figure 5).

Investigation of anti-obesity treatments was carried out within 2011-2013, while numerous researches on pancreatic lipase, medicinal plants and obesity were reported within 2013-2015. Studies discussing phytochemicals were reported in 2016. It is noteworthy that studies discovering inhibition, effects of anti-obesity and pancreatic lipase are rather scarce as indicated by dark green color. Sweileh et al. (2017) [44] reported bibliometric analysis of obesity focusing on its relation to other topics, involved countries and authors. penulis referensi. In this regard, the 
obesity-related topics covered weight reduction and physical activities, while countries dominantly contributing to
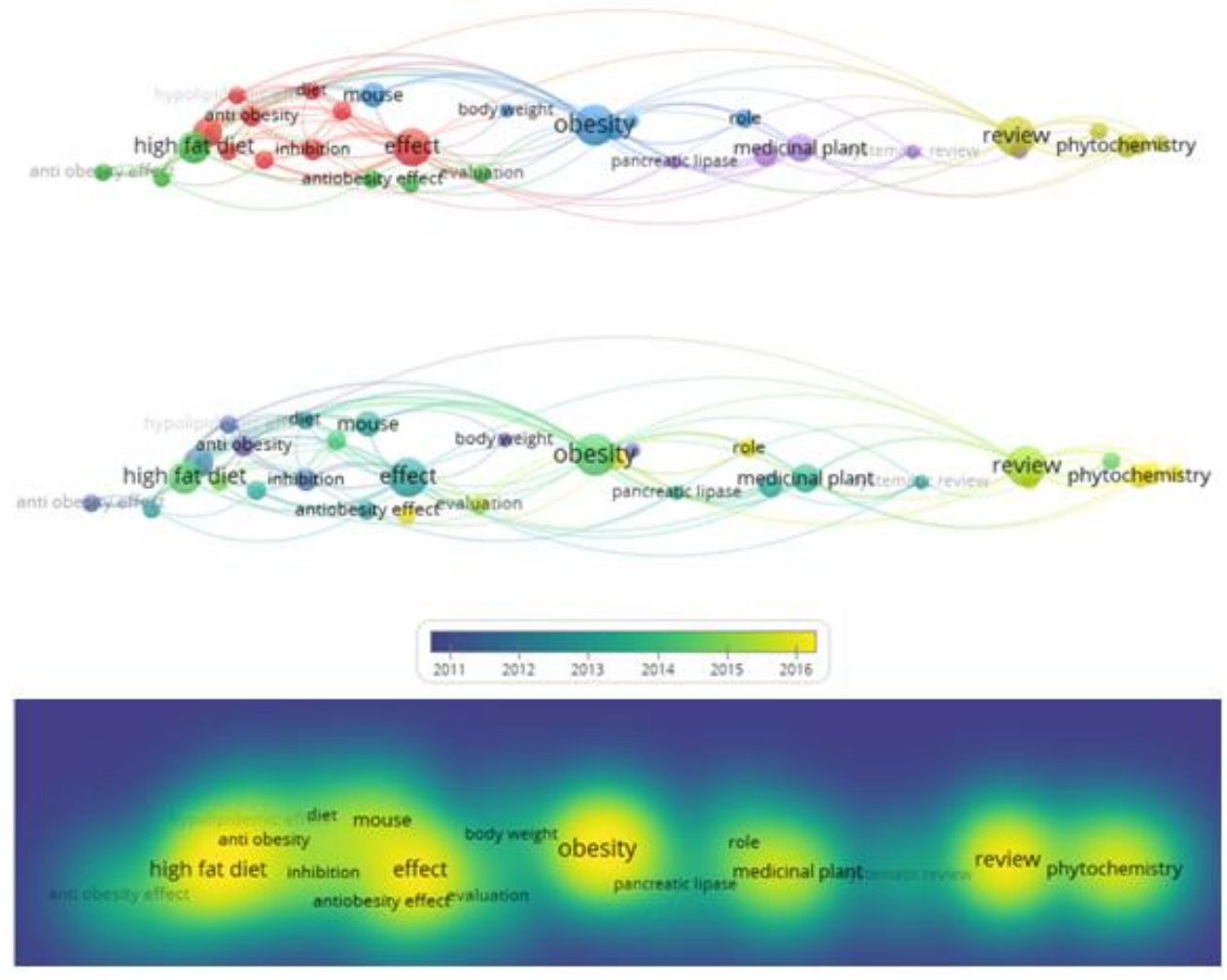

Figure 5. Distribution of medicinal plants and anti-obesity referring to Scopus database.

Scientific data of some Indonesian medicinal plants are unavailable. In several cases, the paper only reported average values and number of samples, but did not inform standard deviation. To deal with this incompletion, effect size was variance $\left(\mathrm{V}_{\operatorname{lnR}}\right)$ [45]. Considering $\%$ inhibition used as indicator, the best data located on the right of vertical line (Figure 6). Using the results of meta-analysis, Indonesian medicinal plants that showed anti-obesity properties included leaves and fruit of asam jawa (Tamarindus indica), asam gelugur (Garcinia atroviridis), Garcinia atroviridis fruit (asam gelugur), lengkuas (Alpinia galanga) rhizome, and kencur (Kaempferia galanga) rhizome. 

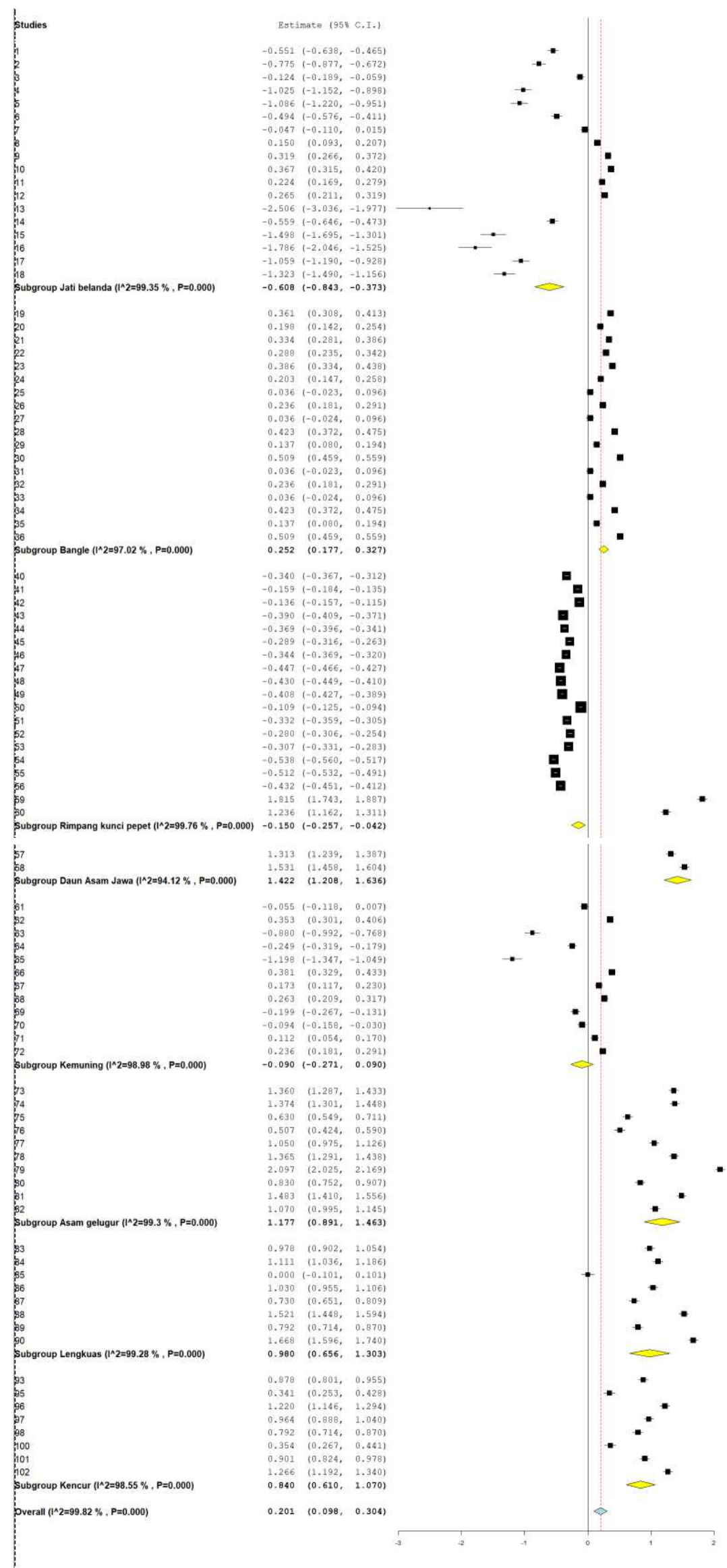
Figure 6. Meta-analysis of Indonesia medicinal plants with anti-obesity properties estimated by their inhibition of pancreatic lipase.

\section{Conclusions}

In general, this present work reported that Moringa oleifera leaves demonstrated the most potential anti-obesity in comparison with other Indonesian medicinal plants. This finding referred to the result of

All authors' responsibilities were as follows: designed the subject and revised the article, H., DNF; developed inclusion and exclusion criteria, developed and performed the search strategy, conducted the statistical analysis and wrote the article FAA, ENQ, H, DNF; screened relevant literature, made decisions according to inclusion and exclusion criteria FAA, ENQ. 


\section{References}

1. Un Ju Jung, Myung-Sook Choi. Obesity and Its Metabolic Complications: The Role of Adipokines and the Relationship between Obesity, Inflammation, Insulin Resistance, Dyslipidemia and Nonalcoholic Fatty Liver Disease. Int J Mol Sci 2014; 15(4): 6184-6223. Doi: 10.3390/ijms 15046184 .

2. World Health Organization. Noncomunicable Disease Country Profil. Genvea: World Health Organization. 2018.

3. Pi-sunyer xavier. The Medical Risks of Obesity. Postgrad Med 2009. 121(6):21-33. Doi: 10.3810/pgm.2009.11.2074.

4. [Riskesdas] Riset Kesehatan Dasar. Report on Result of National Basic Health Research (Laporan Hasil Riset Kesehatan Dasar) 2018. Jakarta (ID): Minsitry of Helath Indonesia.

5. Chaput, J.P., St-Pierre, S., Tremblay, A., Currently available drugs for the treatment of obesity: sibutramine and orlistat. MRMC 2007. 7(1): 3-10.

6. Mahmoud RH, Elnour WA. Comparative evaluation of the efficacy of ginger and orlistat on obesity management, pancreatic lipase and liver peroxisomal catalase enzyme in male albino rats. Eur Rev Med Pharmacol Sci 2013; 17: 75-83.

7. Gude Bujjirao and PK Ratna Kumar. Anti-Obese Therapeutics From Medicinal Plants-A Review. Int J Bioassays $2013 ; 2$ (10): 1399-1406.

8. Halford JC. Obesity drugs in clinical development. Curr Opin Invest Dr 2006; 7(1): 312-318.

9. Melnikova I, Wages D. Anti-obesity therapies. Nat Rev Drug Discov 2006. 5: 369-370.

10. Jong Won Yun . Possible anti-obesity therapeutics from nature - A review. Phytochemistry 2018; 7(1): 1625-1641. Doi: 10.1016/j.phytochem.2010.07.011.

11. Lahrita L. Anti-obesity study of Indonesian medicinal plants : an in vitro study in adipocytes. Hokkaido University: Japan. PhD Thesis 2018. DOI: $10.14943 /$ doctoral.k13325.

12. Ardiyanto D, Triyono A, Novianto F, Mana TA. Effect of obesity jamu to body mass index, waist and mid-upper arm circumference compared with orlistat and evaluation of its safety. Buletin of Health Resaerch Indonesia 2018; 46: 177-182.

13. Zulkarnain Z, Nisa U, Wijayanti E, Fitriani U. 2019. The Effect of two preparation "Jamu" formulas in obesity patients: a randomized, parallel and open label design clinical study. Jurnal Kefarmasian Indonesia 2019, 9, 82-88.

14. Husnawati. Antiobesity activity of red betel (Piper crocatum) extract against high fat diet-induced obesity in rats. IPB University: Bogor. Master Thesis. 2015.

15. Iswantini D, Darusman LK, Fitriyani A. 2010. Uji in vitro ekstrak air dan etanol dari buah asam gelugur, rimpang lengkuas, dan kencur sebagai inhibitor aktivitas lipase pankreas. JSTI 2010; 12: 15-20.

16. Iswantini D, Rahminawati M, Wahyudin A, Trivadila, Nurcholis W. Indonesian medicinal plants extract as anti-obesity: inhibitory effect on the activity of pancreatic lipase by in vitro and in vivo method. Proceedings of ISER $9^{\text {th }}$ International Conference, Berlin, Germany, $30^{\text {th }}$ October 2015.

17. Susanto H, Witjoro A. The effect of black tea as an antiobesity therapeutic agent candidate against IGF-1 as adypogenesis inhibition target. The Journal of Indonesian Medicinal Plant 2011; 4:88-94.

18. Bhardwaj M, Yadav Poonam, Vashishth D, Sharma K, Ajay Kumar, Jyoti Chahal,Sunita Dalal, Sudhir Kumar Kataria. A Review on Obesity Management through Natural Compounds and a Green Nanomedicine-Based Approach. Molecules 2021; 26(11): 3278. Doi: 10.3390/molecules26113278.

19. Seyyedan A, Alshwash MA, Alshagga MA, Koosha S. Medicinal plants and their inhibitory activities against pancreatic lipase: a review. Evid-based Compl Alt 2015; 1-13.

20. Borenstein, M.; Hedges, L. V.; Higgins, J.P.T.; Rothstein, H.R. Fixed-Effect Versus Random-Effects Models. In Introduction to Meta-Analysis. John Wiley \& Sons, Ltd, 2009; pp. 77-86.

21. Afandi FA, Wijaya CH, Faridah DN, Suyatma NE, Jayanegara A. Evaluation of various starchy foods: a systematic review and meta-analysis on chemical properties affecting the glycemic index values based on in vitro and in vivo experiments. Foods 2021; 10, 1-28. Doi: 10.3390/foods10020364.

22. Nahar s, Faisal FM, Iqbal J, Rahman MM, Yusuf MA. Antiobesity activity of Moringa oleifera leaves against high fat diet-induced obesity in rats. Int J Basic Clin Pharmacol 2016; 5(4):1263-1268. Doi: 10.18203/2319-2003.ijbcp20162427.

23. Redha AA, Perna S, Riva A, Petrangolini G, Peroni G, Nichetti M, Iannello G, Naso M, Faliva MA, Rondanelli M. Novel insights on anti-obesity potential of the miracle tree, Moringa oleifera: A systematic review. J Func Foods 2021; 84 (2021). Doi: 10.1016/j.jff.2021.104600.

24. Kim, D., Choi, M., \& Shin, H. Extracts of Moringa oleifera leaves from different cultivation regions show both antioxidant and antiobesity activities. J Food Biochem 2020; Doi:10.1111/jfbc.13282.

25. WWF. Future 50 food: a report. 2019. https://www.wwf.org.uk/sites/default/files/2019-02/Knorr_Future_50_Report_FINAL_Online.pdf. Accesed on July, 302021.

26. Sa'ad B, Zaid H, Shanak S, Kadan S. Herbal-derived anti-obesity compounds and their action mechanisms. In Anti-diabetes and Anti-obesity Medicinal Plants and Phytochemicals. Springer: Switzerland, Cham, 2007; 129-144.

27. Rajan L, Palaniswamy D, Mohankumar SK. Targeting obesity with plant-derived pancreatic lipase inhibitors: A comprehensive review. Pharmacol Res 2020; 155:1-34.

28. Hossain MK, Dayem AA, Han J, Yin Y, Kyeongseok K, Subbroto KS, Gwang-Mo Y, Hye YC, Ssang-Goo C. Molecular Mechanisms of the Anti-Obesity and Anti-Diabetic Properties of Flavonoids. Int J Mol Sci 2016; 17(4): 569. Doi: 10.3390/ijms17040569.

29. Li, Y.-Q., Yang, P., Gao, F., Zhang, Z.-W., \& Wu, B. Probing the interaction between 3 flavonoids and pancreatic lipase by methods of fluorescence spectroscopy and enzymatic kinetics. Eur Food Res Technol 2011; 233(1): 63-69. Doi:10.1007/s00217-011-1491-z.

30. Chen G, Li H, Zhao Y, Zhu H, Cai E., Gao Y, Zhang L. Saponins from stems and leaves of Panax ginseng prevent obesity via regulating thermogenesis, lipogenesis and lipolysis in high-fat diet-induced obese C57BL/6 mice. Food Chem Toxicol 201 ; $106(1)$ : 393-403. Doi:10.1016/j.fct.2017.06.012.

31. Iswantini D, Silitonga RF, Martatilofa E, Darusman LK. Zingiber cassumunar, Guazuma ulmifolia, and Murraya paniculata extracts as antiobesity: in vitro inhibitory effect on pancreatic lipase activity. HAYATI J Biosci 2011; 18: 6-10. 
32. Moon SH, Kim MY. Phytochemical profile, antioxidant, antimicrobial and antipancreatic lipase activities of fermented Camellia japonica L leaf extracts. Trop J Pharm Res 2018; 17: 905-912.

33. Budiman I, Tjokropranoto R, Widowati W, Fauziah N, Erawijantari PP. Potency of turmeric (Curcuma longa L.) extract and curcumin as anti-obesity by inhibiting the cholesterol and triglycerides synthesis in HepG2 cells. Int J Res Med Sci 2015; 3:1165-1171.

34. Kim JH, Kim HJ, Kim C, Jung H, Kim YO, Ju JY, Shin CS. Development of lipase inhibitors from various derivatives of monascus pigment produced by Monascus fermentation. Food Chem 2007; 101: 357-364.

35. Pradono DI, Darusman LK, Susanti Ai. Inhibisi lipase pankreas secara in vitro oleh ekstrak air dan etanol daun asam jawa (Tamarindus indica) dan rimpang kunci pepet (Kaempferiae rotundae). Jurnal Natur Indonesia 2011; 13:146-154.

36. Iswantini D, Silitonga RF, Martatilofa E, Darusman LK. Zingiber cassumunar, Guazuma ulmifolia, and Murraya paniculata extracts as antiobesity: in vitro inhibitory effect on pancreatic lipase activity. HAYATI J Biosci 2011; 18: 6-10.

37. Alias N, Leow TC, Ali MSM, Tajudin AA, Salleh AB, Rahman RNZRA. Anti-obesity Potential of selected tropical plants via pancreatic lipase inhibition. Adv Obes Weight Manag Control 2017; 6: 1-11.

38. Sahib NG, Hamid AA, Saari N, Abas F, Dek MSP, Rahim M. Anti-pancreatic lipase and antioxidant activity of selected tropical herbs. Int J Food Prop 2012; 15: 569-578.

39. Ado MA, Abas F, Mohammed AS, Ghazali HM. Anti- and pro-lipase activity of selected medicinal, herbal and aquatic plants, and structure elucidation of an anti-lipase compound. Molecules 2013; 18:14652-68.

40. Ruangaram W, Kato E. Selection of Thai medicinal plants with anti-obesogenic potential via in vitro methods. Pharmaceuticals 2020;13: $1-12$.

41. Megawati, Artanti N, Mulyani H, Darmawan A, Syahrian H, Lotulung PDN, Supriadi E, Widiyarti G, Dewi RT, Meilawati L, Ernawati T, Dewijanti ID, Minarti. In vitro lipase enzyme inhibitory activities of green tea and other herbs. The Indonesian Journal of Nutrition 2020; 9; 48-52.

42. Rahayu S, Fitri L, Ismail YS. Short communication: Endophytic actinobacteria isolated from ginger (Zingiber officinale) and its potential as a pancreatic lipase inhibitor and its toxicity. Biodiversitas 2019; 20:1312-1317.

43. Watanabe D, Kerakawati R, Morita T, Nakamura T, Ueno K, Kumamoto T, Nakanishi W, Ishikawa T, Uzawa J, Seki H, Tachi M, Harada K, Higuchi Y, Chaichantipyuth C. Isolation of $\beta$-sitosterol and digalactopyranosyl-diacylglyceride from Citrus hystrix, a Thai traditional herb, as pancreatic lipase inhibitors. Heterocycles 2009; 78:1497-1505.

44. Sweileh WM, Al-Jabi SW, Abu Taha AS, Zyoud SH, Anayah FMA, Sawalha AF. Bibliometric analysis of worldwide scientific literature in mobile - health: 2006-2016. BMC Medical Inform Decis Mak 2017; 17,:1-12.

45. Shrestha U, Auge RM, Butler DM. A Meta-Analysis of the Impact of Anaerobic Soil Disinfestation on Pest Suppression and Yield of Horticultural Crops. Front Plant Sci 2016; 7: 1-20. 
TABLE

Table 1. List of Indonesian medicinal plants showing anti-obesity effects

\begin{tabular}{|c|c|c|c|c|c|c|c|}
\hline No. & $\begin{array}{c}\text { Plant source } \\
\text { Indonesian name }\end{array}$ & $\begin{array}{l}\text { Species name } \\
\text { (latin name) }\end{array}$ & $\mathrm{IC}_{50}$ & Orlistat (\%) & $\begin{array}{l}\text { Lipase inhi- } \\
\text { bition }(\%)\end{array}$ & $\mathbf{n}$ & $\begin{array}{c}\text { Concentration } \\
(\mathrm{mg} / \mathrm{mL})\end{array}$ \\
\hline 1. & Angkak [34] & Red yeast rice & $61.2 \pm 5.1$ & - & - & 3 & - \\
\hline 2. & Kunci Pepet [35] & Kaempferia rotunda & - & 10.6 & 5.8 & 3 & 0.10 \\
\hline 3. & Daun asam Jawa [35] & $\begin{array}{c}\text { Tamarindus Indica } \\
\text { leaves }\end{array}$ & - & 10.6 & 10.8 & 3 & 0.10 \\
\hline 4. & Asam gelugur [15] & Garcinia atroviridis & - & 10.6 & 41.3 & 3 & 0.10 \\
\hline 5. & Lengkuas [15] & Alpinia galanga & - & 10.6 & 28.2 & 3 & 0.10 \\
\hline 6. & Kencur [15] & Kaempferia galanga & - & 10.6 & 25.5 & 3 & 0.10 \\
\hline 7. & Bangle [32] & $\begin{array}{c}\text { Zingiber cassumunar } \\
\text { Roxb. }\end{array}$ & - & 17.53 & 21.47 & 3 & 0.10 \\
\hline 8. & Jati Belanda [32] & Guazuma ulmifolia & - & 17.53 & 10.70 & 3 & 0.10 \\
\hline 9. & $\begin{array}{l}\text { Kemuning [36] } \\
\text { (IC50 Orlistat: } 1.71 \\
\mu \mathrm{g} / \mathrm{mL})[37]\end{array}$ & Murraya paniculata & $\begin{array}{r}55.18 \\
\mu \mathrm{g} / \mathrm{mL}\end{array}$ & $\begin{array}{c}17.53 \\
99.6 \pm 0.3\end{array}$ & $\begin{array}{c}25.66 \\
75.6 \pm 5.4\end{array}$ & 3 & 0.10 \\
\hline 10. & Pegagan [38] & Centella asiatica & - & $21.0 \pm 0.4^{*}$ & $25.3 \pm 0.4^{*}$ & 3 & 0.25 \\
\hline 11. & Mengkudu [38] & Morinda citrifolia & - & $21.0 \pm 0.4^{*}$ & $25.8 \pm 0.1^{*}$ & 3 & 0.25 \\
\hline 12. & Pare [38] & $\begin{array}{c}\text { Momordica charantia } \\
\text { L. }\end{array}$ & - & $21.0 \pm 0.4^{*}$ & $21.0 \pm 1.3 *$ & 3 & 0.25 \\
\hline 13. & $\begin{array}{l}\text { Meniran } \\
\left(\mathrm{IC}_{50} \quad \text { Orlistat: } 1.71\right. \\
\mu \mathrm{g} / \mathrm{mL})[37]\end{array}$ & Phyllanthus niruri $\mathrm{L}$. & $\begin{array}{r}27.65 \\
\mu \mathrm{g} / \mathrm{mL}\end{array}$ & $99.6 \pm 0.3$ & $76.7 \pm 0.4$ & 3 & 0.50 \\
\hline 14. & $\begin{array}{l}\text { Daun belimbing wuluh } \\
\text { [37] }\end{array}$ & $\begin{array}{c}\text { Averrhoa bilimbi } \mathrm{L} . \\
\text { Leaves }\end{array}$ & $\begin{array}{r}41.45 \\
\mu \mathrm{g} / \mathrm{mL}\end{array}$ & $99.6 \pm 0.3$ & $73.9 \pm 2.0$ & 3 & 0.50 \\
\hline 15. & Daun kumis kucing [37] & $\begin{array}{c}\text { Orthosipon aristatus } \\
\text { leaves }\end{array}$ & $\begin{array}{r}34.74 \\
\mu \mathrm{g} / \mathrm{mL}\end{array}$ & $99.6 \pm 0.3$ & $95.3 \pm 2.0$ & 3 & 0.50 \\
\hline 16. & Sambiloto [37] & $\begin{array}{c}\text { Andrographis } \\
\text { paniculata }\end{array}$ & - & $99.6 \pm 0.3$ & 0 & 3 & 0.50 \\
\hline 17. & Daun salam [37] & $\begin{array}{c}\text { Syzygium polyanthum } \\
\text { leaves }\end{array}$ & - & $99.6 \pm 0.3$ & $38.2 \pm 6.5$ & 3 & 0.50 \\
\hline 18. & Temu ireng [37] & $\begin{array}{c}\text { Curcuma aeruginosa } \\
\text { Roxb. }\end{array}$ & - & $99.6 \pm 0.3$ & $38.2 \pm 6.5$ & 3 & 0.50 \\
\hline 19. & Daun temulawak [39] & $\begin{array}{c}\text { Curcuma zanthorriza } \\
\text { leaves }\end{array}$ & - & - & 16.9 & 3 & 100 \\
\hline 20. & Kunyit [33] & Curcuma longa & - & - & $70.4 \pm 3.4$ & 3 & 0.25 \\
\hline 21. & Kayu secang [40] & Caesalpinia sappan & - & Cetilistat: 55 & 90 & 3 & 0.50 \\
\hline 22. & Serai wangi [40] & Cymbopogon nardus & - & Cetilistat: 55 & $91 \pm 1.5$ & 3 & 1.0 \\
\hline 23. & Daun murbei [40] & Morus alba leaves & - & Cetilistat: 55 & $90 \pm 20.6$ & 3 & 1.0 \\
\hline 24. & Kayu manis [41] & Cinnamomum verum & - & 46.79 & 16.23 & - & 10 \\
\hline 25. & Teh hijau [41] & Camellia sinensis & - & 46.79 & 47.82 & - & 10 \\
\hline
\end{tabular}




\begin{tabular}{|c|c|c|c|c|c|c|c|}
\hline 26. & Jahe [42] & Zingiber officinale & - & 68.90 & 87.30 & 3 & 0.1 \\
\hline 27. & Daun alpukat [39] & $\begin{array}{c}\text { Percea americana } \\
\text { leaves }\end{array}$ & - & - & 92.8 & 3 & - \\
\hline 28. & Sirih [39] & Piper betle & - & - & 9.9 & 3 & - \\
\hline 29. & Lada putih [39] & Piper nigrum & - & - & 24.1 & 3 & - \\
\hline 30. & Daun jambu biji [39] & Psidium guajava leaves & - & - & 99.0 & 3 & - \\
\hline 31. & Daun jambu air) [39] & $\begin{array}{c}\text { Syzygium } \\
\text { samarangense leaves }\end{array}$ & - & - & 85.6 & 3 & - \\
\hline 32. & Buah asam Jawa [39] & Tamarindus indica fruit & - & - & 68.0 & 3 & - \\
\hline 33. & Daun katuk [39] & $\begin{array}{c}\text { Sauropus androgynus } \\
\text { leaves }\end{array}$ & - & - & 9.9 & 3 & - \\
\hline 34. & Jeruk purut [43] & Citrus hystrix & - & 100 & 58.0 & 3 & 0.01 \\
\hline 35. & Jintan hitam [39] & Nigella sativa & - & - & 37.1 & 3 & - \\
\hline
\end{tabular}

$\mathrm{n}=$ replication 